J. Product. \& Dev., 22(1): 29 -38(2017)

\title{
ESTIMATE GENE ACTION FOR GRAIN YIELD AND ITS COMPONENTS IN SOME BREAD WHEAT CROSSES
}

\author{
R. F. Nada, ${ }^{1}$; A. H. Salem ${ }^{2}$;E. E. Hassan ${ }^{1}$ and A.A. . Hassan ${ }^{1}$
}

1-Department of Plant Production, Faculty of Technology and Development, Zagazig University, Egypt.

2- Department of Agronomy, Faculty of Agriculture, Zagazig University, Egypt.

\section{ABSTRACT}

A $6 \times 6$ half diallel was conducted at the Experimental Farm, Faculty of Technology and Development, Zagazig University, Egypt., during the two successive growing seasons 2013/2014 and 2014/2015. The fifteen crosses along with their parental genotypes (Gemmeiza 11 (P1), Sids 12 (P2), Giza 168 (P3), Sahel 1 (P4), Line 18 (P5) and Line 26 (P6)), were evaluated to estimate gene action effects for grain yield and its components. Mean performance of wheat parental genotypes and their $F_{1}$ crosses for grain yield and its components exhibited significant differences for all studied characters. The parental genotypes Gemmeiza 11, Sahel 1 and Giza 168 gave the highest productivity for grain yield/fad. Regarding the $F_{1}$ crosses $(P 3 \times P 5),(P 2 \times P 3),(P 1 \times P 2)$ and $(P 1 \times P 6)$, they gave the highest productivity for grain yield/fad. On the other hand, the parental genotypes Line 18 (P5) and Line 26 (P6) and $F_{1}$ crosses $(P 1 \times P 3)$ and $(P 2 \times P 4)$ exhibited the lowest values in grain yield/fad.

The results showed that significant values of additive $(D)$ and dominance $\left(H_{1}\right.$ and $\left.H_{2}\right)$ for all characters, except 1000-grain weight and grain yield/fad., revealing the importance of both additive and non-additive gene action in the inheritance.

The dominance genetic effects $\left(\mathrm{H}_{1}\right.$ and $\left.\mathrm{H}_{2}\right)$ were more than the additive gene effects (D), for number of spikes/plant, spike grain weight (gm.), grain yield/plant and grain yield/fad., showing that these characters were controlled by dominance gene action and could be improved through hybrid breeding method. But the additive gene effects $(D)$ were more than non-additive gene effects $\left(H_{1}\right.$ and $\left.H_{2}\right)$ for number of spikelets/spike, number of grains/spike and 1000-grain weight, showing that these characters is controlled 
by additive gene action in these characters. Narrow sense heritability estimates were high for number of spikelets/spike $(61.256 \%)$ and number of grains/spike (56.584\%).

Keywords: Estimate gene action, grain yield, bread wheat crosses

\section{INTRODUCTION}

The main goal of the breeding wheat program is to develop high yielding cultivars. This could be achieved through; study genetic variation components for wheat genotypes to select promising lines from good crosse combinations (Abd-Allah and Mostafa, 2009).

Creating genetic variability and identifying the most promising parental combinations is a difficult task due to the large amount of available germplasm. This is particularly true when attempting to improve quantitative traits such as grain yield where many genes are involved and environmental influence is present (Mather and Jinks, 1982). Whereas Akram et al. (2008) reported that spike length, grains / spike, 1000-grain weight and grain yield/plant were controlled by dominance gene action, and average degree of dominance was greater than one, it means that these characters controlled by over dominance.

Abd El-Rahman (2013) reported that the additive, dominance and epistatic gene effects were important in controlling the inheritance of number of kernels/spike, days to heading and kernel weight.

Heritability estimates in broad and narrow senses were generally moderate to high for most studied characters in the three crosses. Meanwhile, the values of heritability in narrow sense were low for number of kernels / spike, kernel weight and grain yield / plant in the cross (Giza $168 \times$ Sids 13).

Therefore, the objectives of the present study are to estimate the genetic behavior for grain yield and some of its components in 15 crosses of bread wheat using a $6 \times 6$ half diallel.

\section{MATERIALS AND METHODS}

A field experiment was performed during the two successive 2013/2014 and 2014/2015 seasons at the Experimental Farm, Faculty of Technology and Development, Zagazig University.

Six diverse bread wheat genotypes (Gemmeiza 11, Sids12, Giza 168, Sahel1, Line 18 and Line 26) were sown in the first season 
$2013 / 2014$ at three sowing dates $(15,21$ and 28 November) in order to overcome the differences in flowering time and facilitate hybridization.

All possible parental combinations, excluding reciprocales were made among the six parental genotypes to produce fifteen crosses.

Necessary precautions were adopted during the crossing operations to avoid contaminations of the genetic materials. The pedigree and origin of the six parental wheat genotypes are presented in Table 1.

Table (1): Pedigree and origin of the six parental bread wheat genotypes .

\begin{tabular}{|l|l|l|l|}
\hline No. & Genotypes & Pedigree & $\begin{array}{l}\text { Origin } \\
.\end{array}$ \\
\hline 1 & Gemmeiza 11 & $\begin{array}{l}\text { Bow"s"/Knz"s"//7c/seri82/3/ Giza 168 /Sakha 61 } \\
\text { GM 7892 -2GM-1GM-2GM-1GM-0GM }\end{array}$ & Egypt \\
\hline 2 & Sids 12 & $\begin{array}{l}\text { BUC//7C/ALD/5/MAYA74/ON//1160147/3/BB/GL } \\
\text {-VUL//CMH74AA.630/4*SX.SD7096-4SD-1SD-1SD- } \\
\text { OSD }\end{array}$ & Egypt \\
\hline 3 & Giza 168 & MIL/BUC//Seri:CM93046-8m-oy-om-2y-OB. & Egypt \\
\hline 4 & Sahel 1 & N.S.732/pim/Vee"s" CR735-4SD-1SD-1SD-OSD & Egypt \\
\hline 5 & Line 18 & WBLLI*2/KIRITATI & \\
\hline 6 & Line 26 & MIL/BUC//SERI & \\
\hline
\end{tabular}

The seed of the fifteen $F_{1}$ crosses along with the six parental were sown and evaluated for yield and its components in the second season 2014/2015. Sowing date was on 15 November 2014. Nitrogen fertilizer was added as ammonium sulphate $(20.6 \% \mathrm{~N})$, with the rate of $75 \mathrm{~kg}$. $\mathrm{N} /$ fad. This quantity was divided in two equal doses.

The first dose was applied prior to tillering stage, while the second dose was applied prior stem elongation stage.

The design of the experiment was randomized complete blok design with three replications. The experimental plot consists of six rows, $3 \mathrm{~m}$. long (two for each parents of each cross and two for their $\mathrm{F}_{1}$ ). Inter row and inter plant distances were kept at $15 \mathrm{~cm}$., and $5 \mathrm{~cm}$., respectively.

All recommend practices for wheat production and inputs like irrigation and weed control were kept uniform for all wheat genotypes 
from sowing till harvesting to minimize environmental variation to the maximum extent.

The following data were recorded based on individual plant basis:

Yield and its components:

1 - Number of spikes/plant.

2- Number of spikelets/spike.

3 - Number of grains/spike.

4-1000-grain weight (gm.).

5-Spike grain weight (gm.).

6- Grain yield/plant (gm.).

7-Grain yield/fad. Average grain yield $/ m^{2}$ were estimated for each genotype in each replication and the yield of grains (ardab/fad.) was calculated.

\section{Statistical analysis:}

The collected data were subjected to the standard analysis of variance of the randomized complete blocks design according to Snedecor and Cochran (1989). According to Hayman (1954a\&b) and jinks (1954), the components of $\mathrm{D}, \mathrm{H}_{1}, \mathrm{H}_{2}, \mathrm{~h}^{2}, \mathrm{~F}$ and $\hat{\mathrm{E}}$ were calculated.

\section{RESULTS AND DISCUSSION}

Mean performance of wheat parental genotypes and their $\mathrm{F}_{1}$ crosses for grain yield and its components are presented in Table (2).

The results showed significant differences among parental wheat genotypes for all studied characters. Similar finding was also reported by Abd Allah and Mostafa (2009). Number of spikelsts /spike varied from 17.53 to 22.00 for parental wheat genotypes and from 18.87 to 22.00 for $\mathrm{F}_{1}$ crosses.

Regarding number of spikes/plant, it chenged from 5.03 to 8.90 for parental wheat genotypes and from 5.68 to 8.73 for $F_{1}$ crosses. Number of grains/spike ranged from 46.37 to 74.67 for parental wheat genotypes and from 42.70 to 66.97 for $F_{1}$ crosses. 
Table (2). Mean performance of parental genotypes and their $F_{1}$ crosses for grain yield and its component characters.

\begin{tabular}{|lccccccc|}
\hline Genotypes & $\begin{array}{c}\text { No. of } \\
\text { spikelets/ } \\
\text { Spike }\end{array}$ & $\begin{array}{c}\text { No. of } \\
\text { spikes/ } \\
\text { plant }\end{array}$ & $\begin{array}{c}\text { No. } \\
\text { of grains/ } \\
\text { spike }\end{array}$ & $\begin{array}{c}\text { Spike } \\
\text { grain } \\
\text { weight } \\
\text { (gm.) }\end{array}$ & $\begin{array}{c}\mathbf{1 0 0 0 -} \\
\text { grain } \\
\text { weight } \\
\text { (gm.) }\end{array}$ & $\begin{array}{c}\text { Grain } \\
\text { yield } \\
\text { plant } \\
\text { (gm.) }\end{array}$ & $\begin{array}{c}\text { Grain } \\
\text { yield } \\
\text { fad/ } \\
\text { (ardab) }\end{array}$ \\
\hline Gemmeiza11(P1) & 21.40 & 5.03 & 64.23 & 3.09 & 50.36 & 11.59 & 27.92 \\
Sids 12 (P2) & 21.23 & 5.30 & 74.67 & 3.26 & 42.13 & 12.53 & 24.67 \\
Giza 168 (P3) & 19.00 & 6.03 & 46.37 & 2.39 & 47.79 & 12.03 & 25.79 \\
Sahel 1 (P4) & 22.00 & 6.23 & 57.27 & 2.91 & 51.11 & 9.64 & 25.80 \\
L18 (P5) & 21.67 & 7.97 & 54.83 & 2.54 & 52.56 & 11.84 & 21.86 \\
L26 (P6) & 17.53 & 8.93 & 48.30 & 2.46 & 45.27 & 7.48 & 24.73 \\
P1 x P2 & 20.67 & 5.83 & 67.47 & 3.43 & 50.97 & 14.66 & 28.03 \\
P1 x P3 & 21.07 & 5.97 & 59.47 & 2.96 & 47.55 & 10.21 & 20.65 \\
P1 x P4 & 20.80 & 6.40 & 59.33 & 2.67 & 50.92 & 12.74 & 24.12 \\
P1 x P5 & 20.53 & 6.70 & 56.20 & 3.49 & 55.44 & 12.83 & 25.49 \\
P1 x P6 & 20.60 & 6.33 & 58.27 & 2.60 & 54.84 & 13.98 & 27.90 \\
P2 x P3 & 19.40 & 7.57 & 55.10 & 2.74 & 49.74 & 12.67 & 28.18 \\
P2 x P4 & 20.47 & 7.53 & 59.07 & 3.31 & 50.69 & 12.25 & 23.56 \\
P2 x P5 & 20.60 & 5.90 & 66.97 & 3.37 & 48.19 & 11.56 & 27.61 \\
P2 x P6 & 19.47 & 6.90 & 60.73 & 2.63 & 51.64 & 11.80 & 26.35 \\
P3 x P4 & 20.97 & 7.63 & 61.30 & 3.17 & 51.81 & 15.42 & 26.25 \\
P3 x P5 & 20.33 & 6.42 & 61.03 & 2.99 & 49.13 & 16.77 & 28.36 \\
P3 x P6 & 18.87 & 5.68 & 42.70 & 2.45 & 49.38 & 10.24 & 24.50 \\
P4 x P5 & 22.00 & 7.37 & 59.53 & 3.26 & 52.54 & 13.08 & 27.30 \\
P4 x P6 & 20.53 & 7.40 & 55.80 & 3.21 & 55.19 & 13.61 & 27.45 \\
P5 X P6 & 20.67 & 8.73 & 60.63 & 3.21 & 50.44 & 13.97 & 27.48 \\
\hline Mean & $\mathbf{2 0 . 4 6}$ & $\mathbf{6 . 8 2}$ & $\mathbf{5 4 . 8 6}$ & $\mathbf{3 . 0 3}$ & $\mathbf{4 9 . 9 6}$ & $\mathbf{1 3 . 0 5}$ & $\mathbf{2 6 . 2 2}$ \\
\hline LSD 0.05 & $\mathbf{1 . 2 6 0}$ & $\mathbf{0 . 8 9 6}$ & $\mathbf{4 . 1 8 7}$ & $\mathbf{0 . 4 4 7}$ & $\mathbf{7 . 7 5 0}$ & $\mathbf{2 . 2 2 7}$ & $\mathbf{3 . 9 1 9}$ \\
\hline
\end{tabular}

Spike grain weight varied from 2.39 to 3.26 (gm.) for parental wheat genotypes and from 2.45 to 3.49 (gm.) for $F_{1}$ crosses. 1000-grain weight fluctuated from 42.13 to 52.56 (gm.) for parental wheat genotypes and from 54.84 to 55.44 (gm.) for $F_{1}$ crosses. Mean performance for grain yield/plant of six parental wheat genotypes and their $F_{1}$ crosses ranged from 7.48 to 12.53 (gm.) for parental genotypes and from 10.21 to 16.77 (gm.) for $F_{1}$ crosses. In this connection great difference between parental wheat genotypes and their $F_{1}$ crosses were also reported by Abd Allah and Mostafa (2009), Majeed et al., (2011), Shabbir et al., (2011) and Ali and Sulaiman (2014).

The obtained results provide evidence of that wheat parental genotypes Sids 12 and Giza 168, as well as $\mathrm{F}_{1}$ crosses $(\mathrm{P} 3 \times \mathrm{P} 5),(\mathrm{P} 3 \times \mathrm{P} 4)$ and $(\mathrm{P} 1 \times \mathrm{P} 2)$ gave the highest productivity of grain yield/plant. Mean performance of grain yield/fad. ranged from 21.86 to 27.92 for parental 
genotypes and from 20.65 to 28.36 for $F_{1}$ crosses. The parental genotypes Gemmeiza 11, Sahel 1 and Giza 168 gave the highest productivity for grain yield/fad. Regarding the $\mathrm{F}_{1}$ crosses $(\mathrm{P} 3 \times \mathrm{P} 5),(\mathrm{P} 2 \times \mathrm{P} 3),(\mathrm{P} 1 \times \mathrm{P} 2)$ and $(\mathrm{P} 1 \times \mathrm{P} 6)$, they gave the highest productivity for grain yield/fad. On the other hand, the parental genotypes Line 18 and Line 26 and $\mathrm{F}_{1}$ crosses $(\mathrm{P} 1 \times \mathrm{P} 3)$ and $(\mathrm{P} 2 \times \mathrm{P} 4)$ exhibited the lowest values in grain yield/fad. The genetic differences existed among parental wheat genotypes and their $\mathrm{F}_{1}$ crosses, reveal that the studied materials differed in genes controlling the previous characters.

Genetic parameters (Hayman, 1954a and b) are given in Tables (3 and 4 ), and indicated that both additive (D) and dominance $\left(\mathrm{H}_{1}\right.$ and $\left.\mathrm{H}_{2}\right)$ genetic variance were significant for all characters in this study, except 1000-grain weight and grain yield/fad., revealing the importance of both additive and non-additive gene action in the inheritance. These results are in agreement Abd Allah and Mostafa (2009), El-Awady (2011) and Khaled (2013).

The additive genetic variance (D) was significant for all studied traits, except number of kernels/ spike and grain yield/ plant. Kumar and Sharma (2008) reported that additive genetic variance was involved in the genetic of grains/spike and 1000-grain weight. Whereas, spikes/plant and grain yield/plant were under non-additive genetic control.

The dominance gene effects $\left(\mathrm{H}_{1}\right.$ and $\left.\mathrm{H}_{2}\right)$ were more than the additive gene effects (D) for number of spikes/plant, spike grain weight (gm.), grain yield/plant and grain yield/fad showing that this character was controlled by dominance gene action and could be improved through hybrid breeding method. But the additive gene effects (D) were more than non-additive gene effects $\left(\mathrm{H}_{1}\right.$ and $\left.\mathrm{H}_{2}\right)$ for number of spikelets/spike, number of grain/pike and 1000-grain weight, showing that these characters are controlled by additive gene action. Nazir et al., (2014) reported that, number of grains /spike and 1000 grain weight were controlled by partial dominance with additive type of gene action.

The dominance component $\left(\mathrm{H}_{1}\right)$ was more than $\left(\mathrm{H}_{2}\right)$ one, for all characters in this study, except grain yield/fad., showing that dominance and recessive genes were un-equally distributed in the parents. These results are confirmed by the value of $\left[\mathrm{H}_{2} / 4 \mathrm{H}_{1}\right]$ which was less than its maximum value (0.25). The results are in agreement with those obtained by Kutlu and Olgun (2015) and Kandil et al. (2016).

$F$ values indicates the relative frequency of dominant and recessive alleles in the parents was positive and significant, indicating that parental genotypes contained more dominant alleles than the recessive ones respective whether they increase or decrease mean performance of number 
Table (3). Additive (D), dominance (H) genetic variances and their derived parameters for number of spikes/plant, number of spikelets / spike, number of grains/spike, spike grain weight/(gm.), in diallel bread wheat crosses.

\begin{tabular}{|lllll|}
\hline Genetic Components & $\begin{array}{l}\text { No. of } \\
\text { spikes /plant }\end{array}$ & $\begin{array}{l}\text { No. of } \\
\text { spiekliets } \\
\text { /spike }\end{array}$ & $\begin{array}{l}\text { No. of } \\
\text { grains/spike }\end{array}$ & $\begin{array}{l}\text { Spike grain } \\
\text { weight /gm }\end{array}$ \\
\hline Genetic parameters $\boldsymbol{D}$ & $2.283^{* *}$ & $2.941^{* *}$ & $108.356^{* *}$ & $0.106^{* *}$ \\
$\mathrm{H}_{1}$ & $2.864^{*}$ & $1.155^{* *}$ & $89.454^{* *}$ & $0.339^{* *}$ \\
$\mathrm{H}_{2}$ & $2.248^{*}$ & $0.737^{* *}$ & $75.249^{* *}$ & $0.273^{* *}$ \\
$\mathrm{~F}$ & 1.947 & $1.953^{* *}$ & $66.260^{*}$ & 0.060 \\
$\mathrm{~h}^{2}$ & 0.107 & $-0.145^{*}$ & 3.114 & $0.173^{* *}$ \\
$\mathrm{E}$ & 0.099 & $0.261^{* *}$ & 2.787 & $0.025^{*}$ \\
Derived Parameters & & & & \\
{$\left[\mathrm{H}_{1} / \mathbf{D}\right]^{0.5}$} & 1.120 & 0.627 & 0.909 & 1.785 \\
$\mathrm{H}_{2} / 4 \mathrm{H}_{1}$ & 0.196 & 0.159 & 0.210 & 0.201 \\
$\mathrm{~h}^{2} / \mathrm{H}_{2}$ & 0.047 & -0.196 & 0.041 & 0.634 \\
$\mathrm{KD} / \mathrm{KR}$ & 2.229 & 3.253 & 2.014 & 1.378 \\
$\mathrm{~h}(\mathbf{n} . \mathbf{s}), \%$ & 41.876 & 61.256 & 56.584 & 37.620 \\
\hline & $*, *$ Significant on 0.05 and 0.01 levels of probability, respectively. & \\
\hline
\end{tabular}

Table (4). Additive (D), dominance (H) genetic variances and their derived parameters for 1000-grain weight (gm.), grain yield / plant (gm.) and grain yield/ fad., in bread wheat crosses.

\begin{tabular}{|lccc|}
\hline Genetic Component & $\begin{array}{c}\text { 1000 grain } \\
\text { weight /(gm.) }\end{array}$ & $\begin{array}{c}\text { Grain yield } \\
\text { / plant (gm.) }\end{array}$ & $\begin{array}{c}\text { Grine Yield of/ } \\
\text { fad (ardab) }\end{array}$ \\
\hline Genetic Parameters D & $5.590^{*}$ & $3.048^{* *}$ & 1.924 \\
$\mathrm{H}_{1}$ & 4.979 & $15.887^{* *}$ & 2.023 \\
$\mathrm{H}_{2}$ & 4.469 & $14.385^{* *}$ & 7.557 \\
$\mathrm{~F}$ & 2.357 & 3.809 & $21.657^{* *}$ \\
$\mathrm{~h}^{2}$ & $19.908^{* *}$ & $13.100^{* *}$ & $16.170^{*}$ \\
$\mathrm{E}$ & $9.950^{* *}$ & 0.664 & 2.223 \\
Derived Parameters & & & \\
{$\left[\mathrm{H}_{1} / \text { D }\right]^{0.5}$} & 0.944 & 2.283 & 3.272 \\
$\mathrm{H}_{2} / 4 \mathrm{H}_{1}$ & 0.224 & 0.226 & 0.187 \\
$\mathrm{~h}^{2} / \mathrm{H}_{2}$ & 4.455 & 0.911 & 3.661 \\
$\mathrm{KD} / \mathrm{KR}$ & 1.575 & 1.754 & 0.137 \\
$\mathrm{~h}(\mathrm{n} . \mathrm{s}), \%$ & 14.467 & 7.997 & 0.400 \\
\hline
\end{tabular}

$*, * *=$ Significant on 0.05 and 0.01 levels of probability, respectively. 
of spikelets/spike and grain yield/fad. It was supported by the ratio of $\mathrm{KD} / \mathrm{KR}$, which was greater than unity for these characters.

The sum of dominant alleles in heterozygous phase over all loci, as indicated by $\left(\mathrm{h}^{2}\right)$, was positive and highly significant for spike grain weight (gm.), 1000 grain weight (gm.) and grain yield/plant, while positive and significant for grain yield/fad., showing that dominant genes controlling the genetic mechanism of these characters. El-Awady (2011) reported that dominance gene effect $\left(h^{2}\right)$ was significantly positive for number of grains/spike and grain yield/plant in the three wheat crosses.

The degree of dominance $(\mathrm{H} 1 / \mathrm{D})^{0.5}$ was more than unity for confirming the importance of over-dominance gene action in controlling the inheritance for all characters, except, spikelets/spike, number of grains/spike and 1000 grain weight (gm.). Ali and Sulaiman (2014) reported the values of average degree of dominance was greater than one for number of spikes / plant, number of grains / spike, grain yield / plant.

The proportions of genes with positive and negative effects in the parents as indicated by $\left(\mathrm{H}_{2} / 4 \mathrm{H}_{1}\right)$ were near to theoretical value $(0.25)$, for 1000-grain weight and grain yield/plant, suggesting symmetrical distribution of positive and negative alleles among the parental genotypes.

The proportion of dominant and recessive genes in the parents $(\mathrm{KD} / \mathrm{KR})$ were more than unity, suggesting that dominance genes were more frequent than the recessive ones in the parental genetic make-up for all studies characters except grain yield/fad., which exhibited $(\mathrm{KD} / \mathrm{KR})$ value less than unity.

Narrow sense heritability estimates were high for number of spikelets/spike $(61.256 \%)$ and number of grains/spike $(56.584 \%)$, meanwhile moderate for spike grain weight $(37.620 \%)$ and number of spikes $(41.876 \%)$. while very low for 1000 grain weight /gm. (14.467\%), grain yield/plant gm. (7.997\%) and grain yield/fad., (0.400\%).

\section{REFERENCE}

Abd Allah, M.H. Soheir and A. K. Mostafa (2009). Genetic parameters for some $\mathrm{F}_{1}$ bread wheat (Triticum aestivum L.) crosses. Alex. Sci. Exchange, Journal, 30 (1) 57-66.

Abd El-Rahman, E. Magda, (2013). Estimation of some genetic parameters through generation mean analysis in three bread wheat crosses Alex. J. Agric. Res., 58(3):183-195. 
Akram Z, Ajmal SU, Munir M, Shabir G. (2008). Genetic determination of yield related attributes in bread wheat. Sarhad J. Agric., 24(3): 431-438.

Ali, I. H. and F. S. Sulaiman, (2014). Analysis of combining ability, gene action and heterocyst in a full diallel cross of bread wheat. Mesopotamia Journal of Agric. , 22 (1): 255-269.

El-Awady, A. Wafaa, (2011). Analysis of yield and its components using five parameters for three bread wheat crosses. Egypt. J. Agric. Res., 89 (3): 993-1003.

Hayman, B.I. (1954a). The theory and analysis of diallel crosses. Genetics, 39: 789-809.

Hayman, B.I. (1954b). The analysis of variance of diallel tables. Biometrics, 10: 235-244.

Jinks, J.L., (1954).The analyses of continuous variation in a diallel crosses of Nicotiana rustica L. varieties .Genetics, 39:767-788.

Kandil, A.A., A.E. Sharief, Hasnaa S.M. Gomaa (2016). Estimates of gene action for yield and its components in bread wheat Triticum aestivum $L$. Int. J. Agri. Agri. Res., 8: 34-40.

Khaled, M. A. I. (2013). Genetic system controlling the yield and its components in three bread wheat (Triticum aestivum L.) crosses, Egypt. J. Agric. Res., 91(2):641-653.

Kumar, A. and S.C. Sharma. (2008). Genetic analysis of grain yield and its component traits in bread wheat under rain fed and irrigated condition. Indian J. Agri. Sci. 42(3):367-384.

Kutlu, I. and M. Olgun (2015). Determination of genetic parameters for yield components in bread wheat. Inter. J. of Biosciences , 6 (12): 61-70.

Majeed, S., M. Sajjad and S.H. Khan. (2011). Exploitation of non-additive gene actions of yield traits for hybrid breeding in spring wheat. J. Agri. Soc. Sci. 7(4):131-135.

Mather, K. and J.L. Jinks (1982). Biometrical Gentics. $3^{\text {rd }}$. Chapman and Hall Ltd. London.

Nazir, A., I. khaliq, J. Farooq, K. Mahmood, A. Mahmood, M. Hussain and M. Shahid (2014). Pattern of inheritance in some yield related parameters in spring wheat (Triticum aestivum L.). American J. of Bio. and Life Sci., 2(6): 180-186.

Shabbir, G., N.H. Ahmad, Z. Akram and M.I. Tabassum. (2011). Genetic behaviour and analysis of some yield traits in wheat (Triticum aestivum L.) genotypes. J. Agri. Res.,49(1):1-9.

Snedecor, G.W. and W.G. Cochran, (1989), Statistical Methods. Eighth Edition, Iowa State University Press. 


\section{تقدير الفعل الجيني لمحصول الحبوب ومكوناته في هجن قمت الخبز}

رجب فتحي ندا' ، عبدالحميا حسن سلام `، السيد السبد حسن 'و علي عبدالحميا حسان'

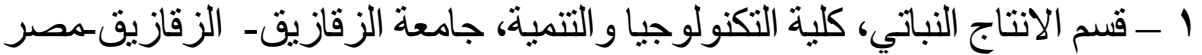

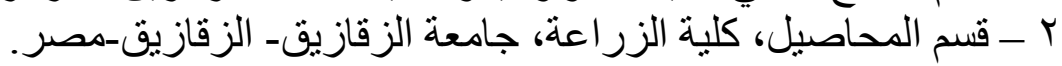

أُجري هذا البحث باستخدام برنامج التهجين النصف دائري بالمزرعة

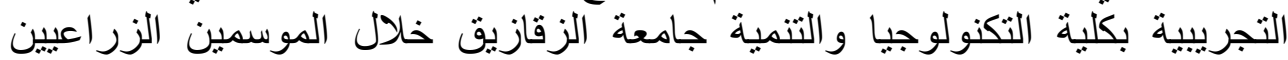

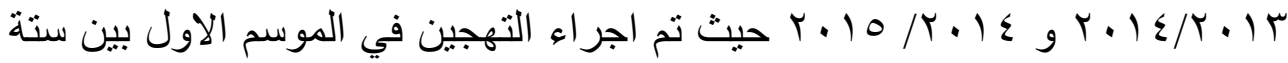

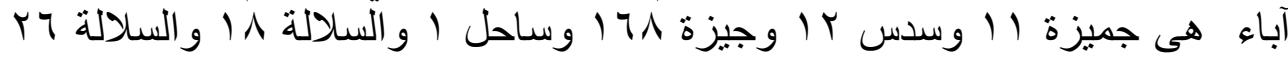

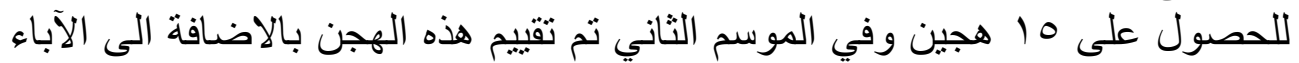

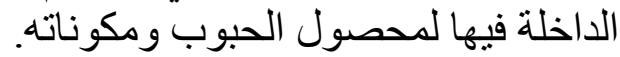

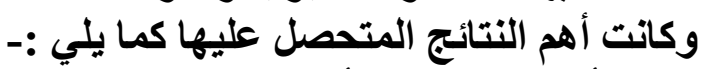

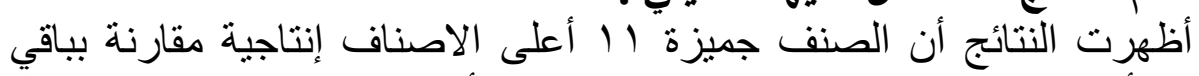

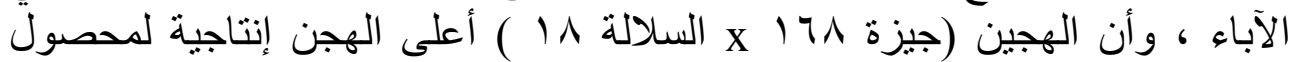

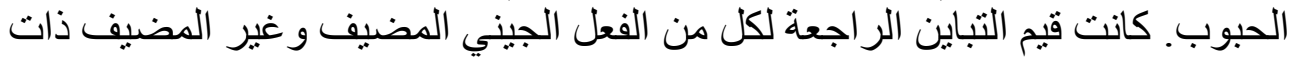

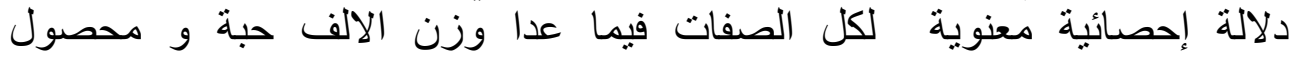
الحبوب/الفدان، ما يشير الى الهمية كل من الفعل الجيني المضيف وغنيف وغير المضيف في وراثة هذه الصفات.

كانت تأثيرات الفعل الجيني السيادي أكبر من تأثثرات الفير الفعل الجيني المضيف

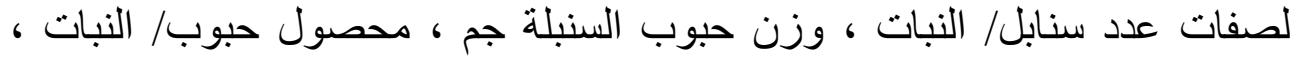
محصول حبوب/الفدان مما يشير الى ألى أهمية الفعل الجيني السيادي في في وراثة هذبة هذبه

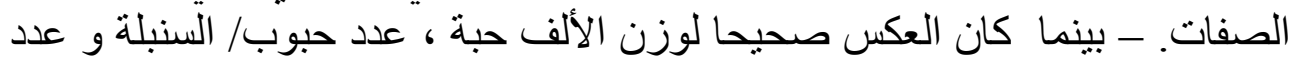

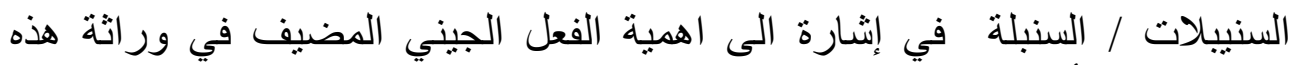
الصفات. كما أشارت النتائج الى إرتفاع كفاءة التوريث لعدد السنيبلات / السنبلة (

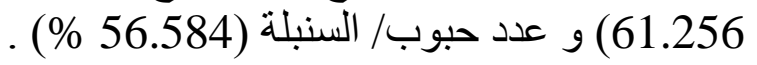

